TRIDARMA: Pengabdian Kepada Masyarakat (PkM), 5 (1) (2022) 39-48

Published by: Institute of Computer Science (IOCS)

TRIDARMA: Pengabdian Kepada Masyarakat (PkM)

Journal homepage: www.iocscience.org/ejournal/index.php/abdimas

\title{
Pelatihan Aplikasi Microsoft Office Pada Yayasan Tarbiyatul Yatim
}

\author{
Danu Putra Rachmana1, Marliani Kusuma Putri², F. Siti Marlina ${ }^{3}$ \\ Sistem Informasi, \\ Universitas Nusa Mandiri, Jl. Raya Jatiwaringin No.2 RW 13 Cipinang Melayu, DKI \\ Jakarta, Indonesia \\ Email: 1Dhanuputra007@gmail.com 2.Marlianiputri21@gmail.com \\ 3.siti.smr@nusamandiri.ac.id \\ Abstrak
}

\begin{abstract}
Teknologi Informasi dan Komunikasi (TIK) pada jaman sekarang sangat dibutuhkan oleh santriwan-santriwati dan tenaga pengajar di Yayasan Tarbiyatul Yatim. Khususnya pada anak-anak, sangat dibutuhkan pelatihan penggunaan perangkat teknologi informasi dan komunikasi agar nantinya anak-anak dapat memanfaatkannya dengan baik. Para santriwan-santriwati dan tenaga pengajar belum bisa menggunakan Microsoft Excel dan Power Point dikarenakan disekolah tidak diajarkan, mahalnya biaya kursus komputer di kalangan santriwan-santriwati daerah Cililitan. Salah satunya adalah dengan melatih kemampuan memanfaatkan aplikasi pengolah kata yaitu Microsoft Word. Kegiatan pengabdian pada masyarakat dititik beratkan dalam bentuk pelatihan tentang cara mengaplikasikan Microsoft Office bagi santriwan-santriwati dan tenaga pengajar Yayasan Tarbiyatul Yatim Diharapkan dengan adanya pelatihan tersebut, santriwan-santriwati dan tenaga pengajar dapat lebih mengetahui tentang teknik penggunaan Microsoft Office dengan memanfaatkan Microsoft Word, Microsoft Excel, Microsoft Power Point.Hasil dari kegiatan pengabdian yang dilaksanakan memberikan pengalaman dan ketrampilan bagi santriwan-santriwati dan tenaga pengajar dalam penggunaan Microsoft Oiffce. Dengan demikian, pelaksanaan kegiatan pengabdian kepada masyarakat di Yayasan Tarbiyatul Yatim Menggunakan Microsoft Word memberikan manfaat yang signifikan bagi peningkatan keterampilan santriwan-santriwati dan tenaga pengajar dalam memanfaatkan teknologi informasi dan komputer, mereka sangat berantusias untuk mengikuti kegiatan lebih lanjut. Mereka sudah mengerti dan dapat mengoperasikan Microsoft Office.
\end{abstract}

Kata Kunci: Microsoft Office, Komputer, Teknologi, Santriwan-Santriwati.

\section{Pendahuluan}

Pelatihan aplikasi Ms.Excel tentang operasi hitung menunjukkan bahwa pengetahuan dan keterampilannya dalam mengoperasikan aplikasi untuk meningkatkan cara menghitung dan mendapatkan hasil dengan menggunakan rumus-rumus dalam aplikasi Ms. Excel. (Arif 2020) dalam praktik pengolahan data nilai siswa yang digunakan. Anak-anak, membutuhkan pelatihan penggunaan perangkat teknologi informasi dan komunikasi agar suatu saat nanti anak-anak dapat memanfaatkannya dengan baik, dengan melatih kemampuan mendesain artikel artistik dengan memanfaatkan aplikasi pengolah kata yaitu Microsoft Word.(Dharmawati 2020) Microsoft Word adalah suatu perangkat lunak atau aplikasi pengolah kalimat untuk mendapatkan rangkaian kata yang bisa memberikan informasi yang dapat dimengerti, aplikasi ini dapat memudahkan pekerjaan manusia.(Ayuningtyas et al. 2019) Kegiatan pengabdian pada masyarakat dititik beratkan dalam bentuk pelatihan tentang cara mendesain artikel artistik menggunakan software Microsoft Word bagi siswa-siswi kelas 5 di SDIT Salsabila Al Muthi'in Yogyakarta. Permasalahan pada Yayasan 
Tarbiyatul Yatim adalah kurangnya ilmu pengetahuan dan juga belum diajarkan kepada santriwansantriwati terhadap penggunaan Microsoft Office (Word, Excel dan PowerPoint). Kemudian di Yayasan Tarbiyatul Yatim belum adanya media komputer, sehingga para santriwan- santriwati di Yayasan Tarbiyatul Yatim belum bisa mengenal apa itu Microsoft Office, dan juga kurang begitu memahami bagaimana cara mengoperasikan komputer.(Baihaqi et al. 2021) Oleh karena itu, sangat diperlukan adanya penelitian di berbagai aspek pendidikan, terutama di beberapa instansi pendidikan yang masih tertinggal dalam hal teknologi untuk menunjang pembelajaran dan perkembangan zaman.

1.1 Tujuan kegiatan ini adalah untuk sarana belajar dan melatih santriwan-santriwati menggunakan Aplikasi microsoft office Word, Excel dan Power point. Sehingga santriwan-santriwati Yayasan Tarbiyatul Yatim mampu memanfaatkan sarana yang ada di Komputer untuk kepentingan Tugas dan belajar di kehidupan sehari-hari..

1.2 Manfaat yang diharapkan dari pelatihan ini adalah santriwan-santriwati Yayasan Tarbiyatul Yatim mampu mempelajari dan menerapkan pengetahuan yang diperoleh dari pelatihan microsoft office ini pada peningkatan kualitas santriwan-santriwati Yayasan Tarbiyatul Yatim tersebut.

1.3 Target Luaran dalam kegiatan pengabdian kepada masyarakat ini, yaitu:

a. menambah pengetahuan serta meningkatkan kemampuan santriwan-satriwati dalam penggunaan komputer dan Microsoft Office untuk menjadi ilmu yang bermanfaat bagi Yayasan Tarbiyatul Yatim.

b. santriwan-satriwati mampu mengoperaasikan Microsoft office dalam melaksanakan tugas sekolah dan kehidupan sehari-hari..

\section{Realisasi Kegiatan}

Pelatihan Aplikasi Microsoft Office Pada Yayasan Tarbiyatul Yatim Perencanaan Program dan Kegiatan ini dilakukan dengan cara menggunakan metode pembelajaran seperti di sekolah, dengan mengajari santriwan-santriwati cara membuat biodata, belajar WordArt dari Microsoft Word, membuat tabel di excel dan membuat Persentasi dari Microsoft PowerPoint. Proses pelatihan dilaksanakan selama 4 kali pertemuan masing-masing selama 2,5 jam. Selama proses pelatihan, peserta diberikan modul pelatihan yang dipakai untuk acuan pelatihan. Kegiatan Pelaksanaan Pengabdian Kepada Masyarakat ini akan dilaksanakan pada Tanggal 25 s.d 28 November 2021 dengan rincian sebagai berikut :

Tabel 1. Jadwal Kegiatan Pengabdian Pada Masyarakat

\begin{tabular}{|c|l|c|c|c|c|}
\hline NO & \multicolumn{1}{|c|}{ Kegiatan } & \multicolumn{3}{|c|}{ Jadwal Pelaksanaan Tanggal : } \\
\cline { 4 - 5 } & \multicolumn{2}{|c|}{$\mathbf{2 5}$} & $\mathbf{2 6}$ & $\mathbf{2 7}$ & $\mathbf{2 8}$ \\
\hline 1 & Persiapan Peralatan & & & & \\
\hline 2 & Pengantaran Materi Presentasi Materi & & & & \\
\hline 3 & Test/Latihan & & & \\
\end{tabular}

Tempat pelaksanaan pengabdian kepada masyarakat ini beralamat: Jl. Cililitan Kecil II No.44 RT014 RW007, Kelurahan Cililitan, Kecamatan Kramatjati, Kota Jakarta timur, Provinsi DKI Jakarta 13640.

\subsection{Team pelaksanaan dan Tupoksi}

\begin{tabular}{|c|l|lc|c|}
\hline No & Team Pelaksana & \multicolumn{1}{|c|}{ Tupoksi } & Waktu \\
\hline 1 & Siti Marlina, M.Kom & Penanggung Jawab & November 2021 \\
\hline 2 & Danu Putra R & 1. Pengetahuan dasar tentang & $27-28$ \\
& & MS.Excel & November 2021 \\
& & 2. & Menjelaskan fungsi menu Bar & \\
\hline
\end{tabular}




\begin{tabular}{|c|c|c|c|}
\hline & & 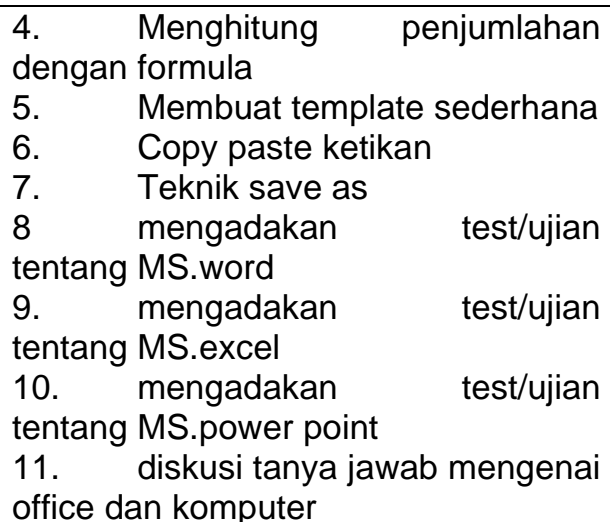 & \\
\hline 3 & Marliani Kusuma Putri & $\begin{array}{ll}\text { 1. } & \text { Pengetahuan dasar tentang } \\
\text { MS. word } & \\
\text { 2. } & \text { Menjelaskan fungsi menu Bar } \\
\text { 3. } & \text { Mengetikan biodata santriwati } \\
\text { 4. } & \text { Membuat desain Word Art } \\
\text { 5. } & \text { Merapihkan ketkan santri } \\
\text { 6. } & \text { Copy paste ketikan } \\
\text { 7. } & \text { Pengetahuan dasar tentang } \\
\text { MS.power point } \\
\text { 8. } \quad \text { Menjelaskan fungsi menu Bar } \\
\text { 9. } & \text { Mendesain slide } \\
\text { 10. } & \text { Membuat tabel } \\
\text { 11. } & \text { Tampilan } \\
\text { 12. } & \text { Pembuatan isi yang menarik } \\
\text { 13. } & \text { Copy paste ketikan } \\
\text { 14. } & \text { Teknik save as }\end{array}$ & $\begin{array}{c}26-27 \\
\text { November } 2021\end{array}$ \\
\hline
\end{tabular}

\subsection{Ringkasan Materi}

\section{a. Microsoft Word}

Microsoft Word adalah aplikasi pengolah kalimat yang termasuk ke dalam software komputer yang biasanya benar-benar merupakan produk asli yang dibuat oleh Microsoft, serta tidak akan ditemui kata yang tidak memberikan informasi yang salah. Selain itu, Microsoft menyediakan upgrade Microsoft Word dengan mudah apabila ingin mengganti ke versi terbaru.(Arif and Masdalipa 2020)

\section{b. Materi Kegiatan Power point}

Power point merupakan salah satu dari program microsoft (MS) office. Program yang lain adalah MS-Word, MS-Exell, MS-Access, dll. Power point adalah paket program yang digunakan untuk membantu pembuatan bahan bagi keperluan presentasi. Berbagai daya dukung untuk pembuatan presentasi telah disediakan di program power point.(Anomeisa and Ernaningsih 2020) Secara garis besar apa yang dikerjakan di power point meliputi: a. Membuka program Power Point Bekerja di lingkungan windows seperti halnya programprogram microsoft yang lain, terlebih dahulu harus dipastikan letak program power point. Untuk memeriksa ada tidaknya program power point tersebut, dapat dilihat melalui berbagai cara. Jika nama power point langsung terlihat sebagai salah satu dari beberapa nama yang lain di layar windows, maka yang demikian itu disebut dengan short cut. Dalam kondisi demikian, untuk membuka program power point dapat langsung klik short cut tersebut. Namun jika di layar utama windows nama power point tidak terlihat, berarti program tersebut berada di menu lain (biasanya berada di menu Programs). Untuk itu harus dipastikan bahwa 
program ada di dalamnya. Berikut ini cara membuka power point bila ada di menu programs. (Catatan: terdapat berbagai cara untuk membuka power point, dalam hal ini bergantung pada seting penampilan program. Cara tersebut akan dengan mudah dilakukan jika pengguna telah familier bekerja dengan windows) b. Membuat Tulisan Jika power point telah siap dengan model layout yang telah ditentukan, maka selanjutnya adalah mengisi form dengan tulisan dan atau gambar sesuai dengan yang dikehendaki c. Pembuatan rancangan tampilan d. Pengaturan animasi tampilan e. Penyajian tampilan f. Mengakhiri program

\subsection{Masyarakat Sasaran}

Para Santriwan santriwati Yayasan Tarbiyatul Yatim dengan usia produktif (6-13 tahun), total yang mengikuti pelatihan ini adalah sebanyak 28 orang santriwan santriwati.

\section{Tinjauan Hasil Yang Di Capai}

Kegiatan pengabdian yang dilaksanakan pada santriwan santriwati Yayasan Tarbiyatul Yatim telah berlangsung dengan baik. Hal ini terlihat dari antusiasme para santriwan santriwati peserta pelatihan sangat tinggi, dibuktikan dengan kehadiran mereka lebih cepat dibandingkan tutor. Kemudian potensi dan kemampuan pembelajaran dari peserta pelatihan terlihat baik, terbukti dari hasil observasi yang dilakukan selama pelatihan berlangsung dan pada saat pendampingan, peserta santriwan santriwati Yayasan Tarbiyatul Yatim mampu mengikuti dan menyelesaikan dengan baik tugas-tugas yang diberikan oleh para tutor. Selain itu pihak Yayasan Tarbiyatul Yatim berharap program ini bisa dilaksanakan secara reguler dan berkala di tahun-tahun selanjutnya dan dengan materi yang lebih luas. Sehingga dapat meningkatkan ketrampilan, memberikan ilmu pengetahuan tentang kemajuan teknologi yang semakin pesat bagi para santriwan santriwati. Dengan adanya keinginan peserta yang kuat untuk dapat mengerti, memahami, dan menguasai materi yang disampaikan juga menjadi faktor pendorong yang mempengaruhi kelancaran pelaksanaan program pengabdian masyarakat ini. animo santriwan santriwati untuk mengikuti kegiatan pelatihan sangat tinggi. Hal ini mengindikasikan bahwa para santriwan dan santriwati menyambut positif kegiatan yang telah dilakukan. Sesuai dengan harapan yayasan, mereka sangat mengharapkan adanya kegitan-kegiatan yang sifatnya memberi penyegaran bagi para santri di daerah ini, baik terkait dengan pendalaman materi bidang studi ataupun terkait dengan metode mengajar dan media pembelajaran. Kepala yayasan dan guru-guru menyambut antusias terkait pelaksanaan kegiatan ini dan berharap pelaksanaan kegiatan dapat dilakukan secara kontinu untuk membantu meningkatkan kualitas santriwan-santriwati di daerah. Dengan demikian kegiatan pengabdian ini telah berlangsung dengan baik. Sehingga bisa disimpulkan Adanya peningkatan pengetahuan dan keterampilan para santriwan santriwati tentang materi Microsoft Word, Excel, Power Point dapat memberi bekal salah satu ketrampilan hard skill untuk menunjang pendidikan. pembuatan media pembelajaran interaktif dengan pendekatan MS Office sebagai sumber pencarian bahan ajar dan santriwan-santriwati juga mampu memanfaatkan komputer sebagai sarana gudang ilmu dalam mengerjakan tugas yang diberikan oleh guru sebagai saran untuk mempresentasikan tugas nya.

\section{Daftar Pustaka}

Anomeisa, Agnesia Bergita, and Dian Ernaningsih. 2020. "Interactive Learning Media Using VBA PowerPoint in Group Data Presentation.” Jurnal Pendidikan Matematika Raflesia 05(01):17-31.

Arif, Alfis. 2020. "Pembuatan Aplikasi Pengolahan Nilai Dengan MS. Excel Bagi Guru SMA Negeri 4 Pagar Alam." Ngabdimas 3(1):27-31. doi: 10.36050/ngabdimas.v3i1.239.

Arif, Alfis, and Risnaini Masdalipa. 2020. "Pelatihan Modul Pembelajaran Abstrak." 03(02):41-51.

Ayuningtyas, Astika, Nurcahyani Dewi Retnowati, Asih Pujiastuti, Yuliani Indrianingsih, and Anton Setiawan Honggowibowo. 2019. "Pelatihan Mendesain Artikel Artistik Menggunakan Microsoft Word Bagi Kelas 5 SD Di SDIT Salsabila Al Muthi'in Yogyakarta." KACANEGARA Jurnal Pengabdian Pada Masyarakat 2(1):13. doi: 10.28989/kacanegara.v2i1.403. 
Baihaqi, Ade, Bayu Aji Laksono, Lot Martua, Batu Bara, Mohamad Abdul Azis, and Risvigo Mirfiandi. 2021. "Pelatihan Dasar Microsoft Office Terhadap Santriwan Santriwati Yayasan Ar-Rahman Krukut." 2(1):2528.

Dharmawati, Dharmawati. 2020. "Pembelajaran Berbasis Komputer Menggunakan Ms. Office 2019 Pada Siswa Di Smk Dwitunggal 1 Tanjung Morawa." Dinamisia: Jurnal Pengabdian Kepada Masyarakat 4(1). doi: 10.31849/dinamisia.v4i1.3751.

Dhewy, Risdiana Chandra. 2018. "Pelatihan Dasar-Dasar Statistika Dengan Menggunakan Aplikasi Microsoft Excel Di Sdn Pamotan li Kecamatan Porong.” Jurnal PADI - Pengabdian MAsyarakat Dosen Indonesia 1(1):36-40. 


\section{Daftar Hadir}

\section{DAFTAR KEHADIRAN SATRIWAN-SANTRIWATI YAYASAN TARBIYATUL YATIM}

\begin{tabular}{|c|c|c|c|}
\hline No & NAMA & HADIR & TIDAK HADIR \\
\hline 1 & Syifa Khainumita & $\checkmark$ & \\
\hline 2 & Najwa Zafn lrawan & $\sqrt{2}$ & \\
\hline 3 & 7alera Nurotus Fitnani & $\sim$ & \\
\hline 4 & Mecus Audéa & $\checkmark$ & \\
\hline 5 & Delisg Fisha Atulda & $\sqrt{2}$ & \\
\hline 6 & Agila Kiram & $\bar{v}$ & \\
\hline 7 & Ilas Barra Farug & $\sqrt{ }$ & \\
\hline 8 & Ilakal Aluqatiob & $\checkmark$ & \\
\hline 9 & Les Putra Aifaria & $\checkmark$ & \\
\hline 10 & Zaki llenawan & $\checkmark$ & \\
\hline II & Noval Rankga Pratams & $\checkmark$ & \\
\hline 12 & Rendi Herdiansyah & $\checkmark$ & \\
\hline 41 & Icha 20lerva Dann llivea & $\sqrt{2}$ & \\
\hline 14 & Mdam Fudres & $\checkmark$ & \\
\hline 15 & Anm Gevatusari & $\checkmark$ & \\
\hline 16. & Dalla Malyzan & J & \\
\hline 17 & Firzan Bossith & $\checkmark$ & \\
\hline 18 & Lukman Nuntalim & 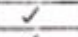 & \\
\hline 19 & Nabul Nimed Natanui & 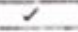 & \\
\hline 20 & Mfuhammas Axha Abqan & $\checkmark$ & \\
\hline 21 & Muri Aulianti & 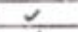 & \\
\hline 22 & Armi & $\checkmark$ & \\
\hline 23 & Miffulud Arma & $\checkmark$ & \\
\hline 24 & Alyz Gust Rolmauza & $\checkmark$ & \\
\hline 25 & Kalils Aumbira & $\checkmark$ & \\
\hline 26 & Hungatectari & 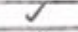 & \\
\hline 27 & Rayza. & $\checkmark$ & \\
\hline 28 & Aguhammad Zuyry Pratama. & 1 & \\
\hline
\end{tabular}

Jakarta, 25 - 28 November 2021

Yang Mengetahur.

Yayastan Tarbiyatul Yatim

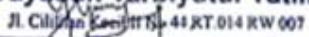

(Yuli Safitri, S.Pd) 


\title{
Surat Keterangan dan Surat Angket Kepuasan Mitra
}

\author{
SURAT PERNYATAAN KESEDIAAN KERJA SAMA DARI \\ YAYASAN TARBIYATUL YATIM \\ Yang bertandatangan di bawah ini: \\ Nama : Yuli Safitri, S.Pd \\ Pimpinan Mitra : Yayasan Tarbiyatul Yatim \\ Bidang Kegiatan : Pengabdian Masyarakat \\ Alamat : J. Cilititan Kecil II No.44 RT014 RW007, Kelurahan Cililitan, \\ Kecamatan Kramatjati, Kota Jakarta timur, Provinsi DKI Jakarta 13640 \\ Dengan ini menyatakan bersedia untuk bekerjasama dengan Pelaksana Kegiatan Pengabdian \\ Masyarakat

$\begin{array}{lrl}\text { Nama Ketua Tim Pengusul } & : & \text { Danu Putra Rachmana } \\ \text { Nomor Induk Mahasiswa } & : & 11207092 \\ \text { Nama Anggota } & : & \text { Marliani Kusuma Putri } \\ \text { Nomor Induk Mahasiswa } & : & 11207093 \\ \text { Program Studi } & : & \text { Sistem Informasi } \\ \text { Nama Dosen Pendamping } & : & \text { Siti Marlina, M.Kom } \\ \text { Perguruan Tinggi } & : \text { Universitas Nusa Mandiri }\end{array}$ \\ Guna menerapkan dan/atau mengembangkan iptek pada tempat kami. \\ Bersama ini pula kami nyatakan dengan sebenarnya bahwa diantara pihak Yayasan dan \\ PelaksanaProgram tidak terdapat ikatan kekeluargan dan ikatan usaha dalam wujud apapun \\ juga. \\ Demikian Surat Pernyataan ini dibuat dengan penuh kesadaran dan tanggung jawab tanpa ada \\ unsur pemaksaan didalam pembuatannya untuk dapat digunakan sebagaimana mestinya.

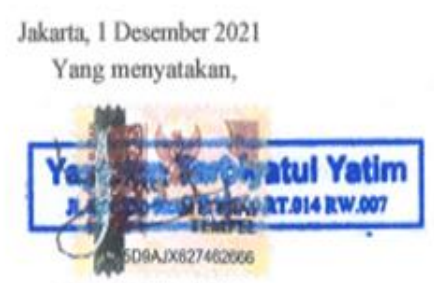

(Yuli Safitri, S.Pd) 
ANGKET KEPUASAN MTRRA TERHADAP

KEGUTAN PENGABDIN KEPADA

MASYARAKATUNIVERSTIS NUSA MANDIRI

Identitus Fengabalian kepada Mangarakat

Judul Kegiatan : PELATHHAN APLIKASI MICROSOFT OFFICE PADA YAYASAN

TARBIYATUL. YATIM
Sifut Kegiatan

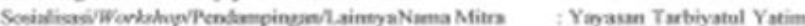

Lokadi Mitra : : M. Citilitan Kecil II No.44 RT014 RW607, Keturahan Clilitan, Kecumasan Kramatjati, Keta Jakarts timur, Provindi DKI Jabarta 13640

Hari/Tankeal : 25 November 2021 - 28 Novomber 2021

Dosen dan Tim Pengabalias

1. Siti Merlina, M Kom

2. Dienu Putra Kachmana

3. Madiani Kerama Putri

Surey Kegeasan Kegiatea P3

(Mitra/ Peserta)

Berikan tands (v) pado jounben yane anda pilit

Ketenamgan
SS - Sangat

Seteipu

S = Setuju

IS - Tidak Setoju

STS = Satgat Tidek Setuja

\begin{tabular}{|c|c|c|c|c|c|}
\hline \multirow{2}{*}{$\mathrm{Na}$} & \multirow{2}{*}{ Permatasan } & \multicolumn{4}{|c|}{ Skabla Penilaina } \\
\hline & & ss & $\mathbf{s}$ & Ts & STS \\
\hline 1. & 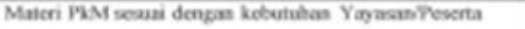 & $\mathbf{v}$ & & & \\
\hline 2. & 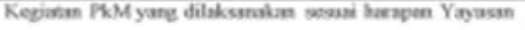 & $\mathrm{v}$ & & & \\
\hline 3. & Capapenateri menyajikan maken PLM metakik & $\mathrm{v}$ & & & \\
\hline 4. & Matain youe dispikan jelus den matah dipahami & $\mathrm{v}$ & & & \\
\hline s. & 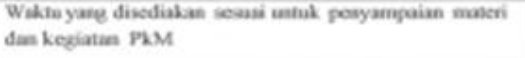 & $\mathrm{v}$ & & & \\
\hline 6. & 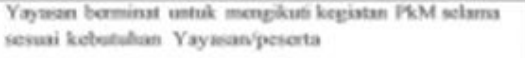 & $\mathrm{v}$ & & & \\
\hline
\end{tabular}




\begin{tabular}{|l|l|c|c|c|c|}
\hline 7. & $\begin{array}{l}\text { Anggota PkM yang terlibat dalam pengabdian masyarakat } \\
\text { memberikan pelayanan sesuai dengan kebutuhan }\end{array}$ & $\mathrm{v}$ & & & \\
\hline 8. & Kegiatan PkM dilakukan secara berkelanjutan & & $\mathrm{v}$ & & \\
\hline 9. & $\begin{array}{l}\text { Setiap keluhan/pertanyaan/permasalahan yang diajukan } \\
\text { ditindaklanjuti dengan baik oleh narasumber/anggota }\end{array}$ & $\mathrm{v}$ & & & \\
\hline 10. & $\begin{array}{l}\text { Yayasan mendapatkan manfaat langsung dari kegiatan PkM } \\
\text { yang dilaksanakan }\end{array}$ & $\mathrm{v}$ & & & \\
\hline 11. & $\begin{array}{l}\text { Kegiatan PkM berhasil meningkatkan } \\
\text { kesejahteraan/kecerdasan Yayasan }\end{array}$ & $\mathrm{v}$ & & & \\
\hline 12. & Secara umum yayasan puas terhadap kegiatan PkM & $\mathrm{v}$ & & \\
\hline
\end{tabular}




\section{Foto Kegiatan}

Dokumentasi Kegiatan Pengabdian Kepada Masyarakat 2021
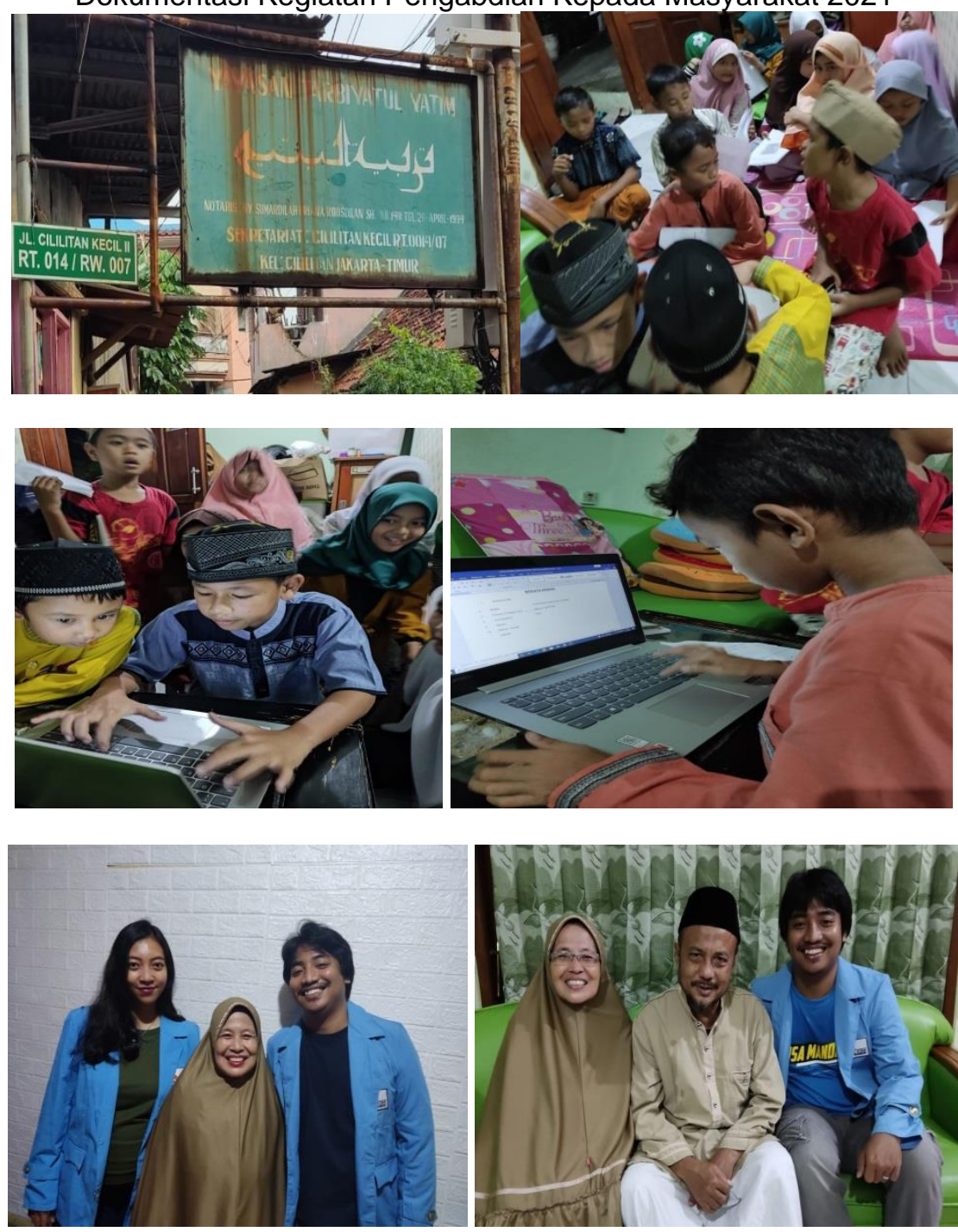